\title{
Between party-systems and identity-politics: the populist and radical right in Estonia and Latvia
}

\section{Stefano Braghiroli \& Vassilis Petsinis}

To cite this article: Stefano Braghiroli \& Vassilis Petsinis (2019): Between party-systems and identity-politics: the populist and radical right in Estonia and Latvia, European Politics and Society, DOI: $10.1080 / 23745118.2019 .1569340$

To link to this article: https://doi.org/10.1080/23745118.2019.1569340

册 Published online: 04 Feb 2019.

Submit your article to this journal

View Crossmark data $־$ 


\title{
Between party-systems and identity-politics: the populist and radical right in Estonia and Latvia
}

\author{
Stefano Braghiroli and Vassilis Petsinis \\ Johan Skytte Institute of Political Studies, University of Tartu, Tartu, Estonia
}

\begin{abstract}
The article explores party-based populist and radical right looking at the cases of Latvia's National Alliance (NA) and of the Estonian Conservative People's Party (EKRE). The research question is: How does the intersection between the specificities of party-systems and particularistic identity-politics either facilitate or complicate the political engagements of EKRE and NA? This piece demonstrates that whereas the Latvian party-system provides the opportunity structure for the inclusion of NA as a legitimate partner into the government coalition, Estonia's mainstream political parties keep on excluding EKRE from the halls of power. This occurrence is highly subject to the different ways that the two-party systems have been dealing with parties suspected of pro-Kremlin leanings (Estonia: Eesti Keskerakond/Centre Party; Latvia: Saskana/Harmony). Meanwhile, the socio-psychological campaigns of both EKRE and NA over immigration and the refugee crisis tend to interlink these two policy-areas with the collective memories of 'colonization' under the Soviets and the collective anxieties of becoming 'colonized' again by others. This socio-psychological strategy has enabled both parties to augment their public appeal.
\end{abstract}

\section{KEYWORDS}

Populist and radical right; party systems; identity politics; refugees; Latvia; Estonia

\section{Introduction}

The populist and radical right in Central and Eastern Europe has been attracting the interest of academic experts (Minkenberg, 2015, 2017; Pirro, 2013; Pytlas, 2015; van Kessel, 2015). However, the academic literature on this party-family in the Baltic States remains limited (Auers \& Kasekamp, 2009, 2013, 2015) and needs to be enhanced. This necessity becomes more urgent taking into consideration that the Baltic States are the three most successfully consolidated democracies inside the post-Soviet space (Meleshevich, 2007). One additional factor that raises the necessity for more extensive treatises of the populist and radical right in the Baltic States is the increasing impact of new catalysts in these societies: immigration and the controversies over the refugee distribution debate. ${ }^{1}$

Of high importance is to examine how populist and radical right-wing parties adapt to specific national settings and how the political circumstances can provide trajectories towards either the inclusion or the exclusion of populist and radical right-wing parties 
in certain countries and during certain periods. Another very timely objective is to set in context how populist and radical right-wing parties can selectively appropriate particularistic identity and memory politics from the pre-existing political cultures in specific countries and embed them into their narratives on up-to-date and hot-button issues (e.g. immigration). This article hints that the more systematic cooperation between academic experts in nationalism and academic experts in right-wing populism would enable the latter to formulate new interpretative models about how (right-wing) populist and Eurosceptic actors embed their agendas inside the pre-existing political cultures of nationalism and particularistic identity and memory politics. The systemization of this interdisciplinary cooperation can be beneficial to the study of right-wing populism not solely in the Baltic States or the Visegrad Four, but also in Western Europe.

This piece demonstrates that whereas the Latvian party-system provides the opportunity structure for the inclusion of the National Alliance (NA) as a legitimate partner into the government coalition, Estonia's mainstream political parties keep on excluding the Estonian Conservative People's Party (EKRE) from the halls of power. This occurrence is highly subject to the different ways that the two-party systems have been dealing with parties suspected of pro-Kremlin leanings (Estonia: Eesti Keskerakond/Centre Party; Latvia: Saskana/Harmony). Meanwhile, the socio-psychological campaigns of both EKRE and NA over immigration and the refugee crisis tend to interlink these two policy-areas with the collective memories of 'colonization' under the Soviets and the collective anxieties of becoming 'colonized' again by others. This socio-psychological strategy has enabled both parties to augment their public appeal. The research question here is: How does the intersection between the specificities of party-systems and particularistic identity-politics either facilitate or complicate the political engagements of EKRE and NA?

This is a paired comparison (Tarrow, 2010) which has relied on a qualitative and discourse analysis of EKRE's and NA's political programmes and other party documents (e.g. electoral manifestos) as well as official statements and declarations. To these should be added semi-structured interviews with top affiliates of EKRE and NA, as well as locally-based academic researchers with an expertise in Populism, Nationalism and Estonian/Latvian party-politics (conducted between 2016 and 2018). Quantitative sources such as public surveys have been of complementary importance. In light of the limited academic literature on the populist and radical right in the Baltic States, this piece has also relied on relevant articles from the Estonian, Latvian and international press. This material has been analyzed through the lens of the relevant academic literature.

The selection of the two cases conforms to the most similar system design (MSSD) approach. Following this logic, the features of the parties studied in this piece appear overall highly comparable and display a high degree of similarity ${ }^{2}$; however, their developmental trajectories diverge greatly when it comes to these parties' capacity to acquire the necessary political centrality in the domestic party system and gain access to the government coalition. The study focuses on the cases of Estonia and Latvia. The context of Lithuania - given the conceptual foundations of this study - appears hardly comparable, considering Lithuania's different ethno-political context and party system. In this respect, Mudde (2007) maintains that "it is incorrect to speak of a "Baltic model," as Lithuania, the third Baltic state, did not follow the ethnocratic model.' 3

In the beginning, this piece introduces the theoretical and scholarly literature on the populist and radical right in Latvia and Estonia. Of particular importance is to isolate the 
fundamental principles of the Bauska Declaration which was signed jointly by the two parties and their Lithuanian partners in 2013. Throughout the article, this summary will help assess how the identitarian agenda of the Bauska Declaration still shapes the political engagements of EKRE and NA. Then, the focus is cast on the operation of the two parties within their respective national contexts from a comparative angle with a stress on the enabling and the disabling conditions of the Latvian and Estonian party-systems. The final section clarifies why and how the two parties have, since 2015, been interlinking the debate over immigration and the refugee crisis with Estonian and Latvian particularistic identity and memory politics.

\section{The populist and radical right in Estonia and Latvia: the state of the art}

The scholarly literature on the populist and radical right in the Baltic States is particularly limited (Auers \& Kasekamp, 2015; Kasekamp, 1999). The relevant literature - in the Estonian and Latvian contexts - has rarely specialized and was often relegated to a chapter of the broader research on party politics in post-Communist Europe (Hanley, 2004; Meleshevich, 2007). One of the key-goals of this study is to contribute towards filling the scholarly gap and reducing its intrinsic parochialism.

The scarcity of scholarly research in the field is acknowledged by the only comparative study by Auers and Kasekamp (2015) where the authors reaffirm the need for empirical analysis on 'the extent to which the radical right has impacted the party system, the political agenda, and ultimately the post-1991 transformation'. In the authors' own words, the need is justified as 'the Baltic States make for interesting comparative case studies of the impact and influence of successful radical right political parties and movements on the political system'. Even the seminal contribution The Far Right in Europe: An Encyclopedia by Jackson and Davies (2008) seems to neglect the Baltic context and relegate it to a mere section of the broader debate in Central and East Europe.

As suggested by Auers and Kasekamp (2015), as well as Lieven (1994), the Estonian and Latvian cases display a high degree of comparability, both in partisan and broader political terms. Both countries regained their independence following the collapse of the Soviet Union and convincingly engaged in successful radical reforms that made them frontrunners in the path towards European and Euro-Atlantic integration. In both political contexts, the acceptance of the narrative of 'return to Europe' has delimited the mainstream political spectrum, while the ethnic divide and the presence of a substantial ethnic Russian minorities, with their partisan representation, has delimited the prospects for coalitions inside the partisan space. Inside this context, the two main parties of the far right have faced different fortunes.

The relevance of the ethnic divide became - following the restoration of the state independence - a key factor of identity building in both Estonia and Latvia. According to Mudde (2007, p. 53)

both newly independent states started their process of state- and nation-building confronted with a huge Russian-speaking population within their borders and a hostile Russian state just beyond them. Particularly in the early 1990s this led to polarization between a self-conscious, nativist Estonian/Latvian parties block, on the one hand, and a marginalized and nostalgic Russophone parties block, on the other. 
This attitude was widely shared in the 1990s by all the key mainstream forces in the two countries. 'The nativist idea of a "Latvian Latvia," combined with "anti-colonization" rhetoric, was common to virtually all Latvian parties' (2007, p. 54). The trend changed in the late 1990 s, when 'nativism became less pronounced and, in both countries, the main party discourses and policies slowly but steadily accepted a multicultural state' (Kelley, 2004). The developments provided the opportunity for a consolidating and again assertive far right in both countries - to present itself as the only patriotic forces standing against the elites' betrayal of the ethno-national soul of the state.

In both contexts, following a phase of consolidation and evolutionary development, nativist parties tried to reduce their parochialism by either increasing their degree of political acceptability among the mainstream parties or by progressively infiltrating them and by - accordingly - transforming the very polarity and dynamics of party politics and competition in the domestic environment as it occurred in the case of Latvia. In this latter case, the limited existing literature often refers the above-mentioned trends as a clear instance of entryism. From this perspective, entryism (Webber, 2009) can be defined a strategy of 'joining a rival organizational field in order to disrupt its operations, sow discontent, manipulate decision-making, and introduce and normalise alternative ideologies' (Dudai, 2017). The term is often associated with a Trotskyist tactic of 'infiltrating larger and more moderate political parties without commitment to their ideology and values in order to change them from within' (Callaghan, 1986, p. 380).

\section{EKRE and NA: ideological pillars, trajectories of evolution and main areas of concern ${ }^{4}$}

On 28 August 2013, EKRE, NA and their Lithuanian partners (Nationalists Union-Tautininky Sajunga) signed the Bauska Declaration in the homonymous town of southern Latvia. ${ }^{5}$ This document sets up the main frame of cooperation among the three parties and, more significantly, consolidates their ideological pillars and shared political values inside the context of a 'Baltic populist and radical right-wing international'.

In the preamble, the three partners bemoan the detrimental impact of 'the looming ideas of cultural Marxism, postmodern multiculturalism and destructive liberalism' across Europe and add that 'our honour and love for our homelands will not let us walk the path of cosmopolitanism'. Further along the text, the three signatories advocate for 'a new national awakening' and pledge to convey and spread 'the positive meaning of nationalism' through 'national education and creative culture'. The crucial requirement to repair the damage and reverse the trauma inflicted on the Baltic nations during the Soviet era forms another major component in the Bauska Declaration. In particular, the document demands 'compensations for the occupation by the Soviet Communist regime and acknowledgement of the occupation (by Russia)'. This is coupled with references to the necessity to prevent 'any violation of our sovereignty and any external intrusions to our domestic affairs'. In regards to immigration, the Bauska Declaration summarizes the signatories' main standpoints in a succinct, yet comprehensive, manner as follows: 'We see the immigration policies of Western Europe as a warning example. The demographic situation in our countries does not allow any new massive immigration into our lands'. 
EKRE was established in 2012 as the evolution of the merger between the, formerly centre-right, People's Union of Estonia ${ }^{6}$ (Eestimaa Rahvaliit) and the, more nationalistic and Eurosceptic, pressure-group Estonian Patriotic Movement (Eesti Rahvuslik Liikumine). In 2011, the remainder of the People's Union commenced talks with the Estonian Patriotic Movement which also comprised EKRE's vice-chairman, Martin Helme. By that time, Mart Helme's (EKRE's current leader) nationalist faction had taken over the People's Union. In EKRE's founding declaration, proclaimed in the central Estonian town of Põltsamaa (24 March 2012), the leadership of the new party vowed to protect the national interest, preserve Estonian traditions and

... offer a viable alternative to the voters who are sick of the forced choice between Andrus Ansip (the then leader of the centre-right liberal Reform Party) and Edgar Savisaar (former leader of the, nominally centrist/centre-left, Centre Party), East and West, left and right. ${ }^{7}$

The party delivered a satisfactory performance in the 2015 elections garnering 8.1 per cent of the vote and 7 seats (Table 1).

$\mathrm{NA}$ also came into existence as result of the merger between the national conservative 'For Fatherland and Freedom' - TB/LNNK ${ }^{8}$ and the more nationalistic 'All for Latvia!-VL' party in 2011. TB/LNNK had been engaging in strong identitarian rhetoric to mark the primacy of the Latvian language, called for limiting the naturalization process of stateless persons (mainly ethnic Russians) and staunchly opposed European federalism during Latvia's accession to the EU. According to Auers and Kasekamp (2013, p. 75), 'All for Latvia!' 'ticks all the necessary boxes for a modern radical right populist party. It has followed the rhetorical master frame of the radical right and has a charismatic leader in Raivis Dzintars, the founder and driving force behind VL!'.

In spite of their similar formation trajectories, a qualitative difference between the political origins of EKRE and NA becomes noticeable. Despite the non-negligible contribution of the Estonian Patriotic Movement, EKRE embedded itself into the pre-existing structure of the People's Union and inherited this party's predominantly rural electorate along the western coastline and in southern Estonia. ${ }^{9}$ Although keen on mobilizing its popular bases of support (e.g. the anti-refugee demonstrations throughout 2016) and coordinating various public manifestations (e.g. the torchlight parades on Estonia's Independence Day), EKRE cannot boast a longstanding tradition of grass-roots activism.

By contrast, there is ample evidence that both of NA's constituent parties have a longer tradition of activism and a more explicit preference for radical patterns of engagement into politics in comparison to their Estonian counterparts. When TB/LNNK and 'All for Latvia!' merged into the NA in 2011, this combination reinvigorated Latvian nationalism.

Table 1. Estonian parliamentary elections (March 2015).

\begin{tabular}{lc}
\hline Political parties & Percentages (\%) and seats \\
\hline Reform Party & 27.7 (30 seats) \\
Centre Party & 24.8 ( 27 seats) \\
Pro Patria and Res Publica Union-IRL & 13.7 (14 seats) \\
Social Democrats-SDE & 15.2 (15 seats) \\
Green Party & 0.9 (0 seats) \\
EKRE & 8.1 (7 seats) \\
Free Party & 8.7 (8 seats) \\
Others & 0.9 (0 seats) \\
\hline
\end{tabular}

Source: Estonian Electoral Committee, 2015. 
Younger activists from 'All for Latvia!' gained influence over much of the existing TB/LNNK party apparatus and progressively hegemonized it, particularly on the grass-roots level. 'All for Latvia!' provided fresh and young political energies, very motivated activists, and 'a charismatic leadership in the Weberian sense of a close bond between leaders and followers' (Auers \& Kasekamp, 2013).

Coming back to EKRE, Euroscepticism forms an important component of the party's engagement into politics and comprises three dimensions: geopolitical, sociocultural, and economic. EKRE holds that the core states within the EU allegedly underestimate the security threat which Russia poses for the Baltic States ('Eurovalimiste Platvorm', 2014). It equally objects to the EU's guidelines for LGBT rights and to Estonia's Cohabitation Act (2016). ${ }^{10}$ As far as the party's economic grievances are concerned, these largely revolve around the EU's pressures on Estonia to participate in the bailout packages for richer member-states with troubled economies within the Eurozone. EKRE deplores the way that 'Estonia has been partially transformed into an area representing the interests of the EU, foreign capital and career advocacy functionaries' ('Konservatiivne Manifest', 2012), demands the taxation of tax-free foreign capital ('Riigikogu', 2015b) and objects to the acquisition of land by foreign nationals. Despite the attempt to interlink the economy with national survival, the economic component in EKRE's narrative is subsidiary and only of secondary importance in comparison to demographic issues and 'older' (the historical legacies from the Soviet era) as well as 'newer' (the refugee question) aspects of identity politics.

Various shades of geopolitical, economic and sociocultural Euroscepticism have been characteristic of NA as well. The party has been investing its hopes on the so-called Intermarium project as the 'remaining heartland of the "true Europe"'. ${ }^{11}$ This would ideally link the far right from the Baltic to the Black Sea and function as a bulwark not only against Putin's 'neo-Bolshevism' encroaching from Moscow, but also against the neoliberal, multicultural, secular and feminist 'neo-Bolshevism' emanating from Brussels. ${ }^{12}$ Prior to the concretization of the Intermarium, TN/LNNK and 'All for Latvia!' had been underlining the cultural exceptionalism of Latvia and traditional Latvian 'Christian' values (claiming that homosexual values are intrinsically alien to Latvia ${ }^{13}$ ), while blaming high inflation and other economic woes on Brussels. As put by Agris Purvinš - a Latvian theorist of Intermarium -

the decline of moral values was provoked by Marxists who later turned into liberals incapable of living with the thousand-years-old traditional values created by their ancestors and constantly making the new utopias. At the same time, the imperialistic tendencies are already restored in Russia, and there is a desire to enslave our nations in order to ensure the buffer zone against the mysterious Western invasion. [...] Nowadays, the security and the future of our nations depend on our ability to unite the Intermarium countries. ${ }^{14}$

Overall, the fundamental principles and main areas of political concern for both EKRE and NA are largely in accordance and highly resonate with the ideological pillars established in the Bauska Declaration. Both parties seem to place an overwhelming stress on identity politics, as well as the overriding necessity for national survival, with subsidiary references to economic nationalism. The principle of national survival largely manifests through the constant and powerful emphasis on demographic issues as well as the provision of extensive parental benefits and other incentives to increase the birth rates in both countries (e.g. 
EKRE, Konservatiivne Programm (2015a), 'Perekond' section; NA, Programma (2017), 'Atbalsts gimenēm' section). Furthermore, the persistence of sociocultural Euroscepticism forms a common denominator in the political agendas and engagement of both EKRE and NA. The two parties tend to perceive the EU as a supranational entity, governed by the guiding principle of postmodern multiculturalism, which often endeavours to import 'alien' cultural norms into the two societies. In addition, neither EKRE nor NA seem to be convinced that membership of the EU can decisively enhance Latvia's and Estonia's security status vis-à-vis Russia. ${ }^{15}$ In Raivis Zeltīts' words, 'NA primarily views Latvia's membership of the EU as a geopolitical and security-related issue ... we do not subscribe to $\mathrm{Mr}$ Juncker's concept of Euro-federalism because it is seriously flawed'. ${ }^{16}$

Despite the commonalities in their formation trajectories and their ideological pillars, there also exist certain differences between EKRE and NA; starting from the latter's longer lineage of political activism. Furthermore, as demonstrated in greater detail later in the text, EKRE largely matches the universal typology of a European populist rightwing party within the specific context of Estonia: Euroscepticism and nativism ${ }^{17}$; antiestablishment rhetoric; and a stress on the hard borders principle and law and order. The party-leadership has fashioned EKRE as a 'modern' party that can address and capitalize on a wide array of timely themes such as: (a) instances of inconsistency and political corruption on the behalf of mainstream parties; (b) any possible manifestations of latent Euroscepticism within the society; (c) environmental concerns (e.g. opposition to the Rail Baltic project). By contrast, in the case of NA, the 'essentially' populist features, such as anti-establishment speech, appear to be weaker whereas a more emphatic stress is put on nativism and the necessity to increase Latvia's birth-rate.

Nevertheless, the essential qualitative difference between the two parties revolves around their accessibility to the government structures. Since the (early) parliamentary elections of 2011, NA has been participating in two government coalitions and this testifies to the party's inclusion by its political partners. By contrast, EKRE largely remains an outcast party. This divergence has been of decisive significance towards shaping the two parties' agendas and their respective patterns of engagement into politics. The following section sets in context those catalysts which have provided the opportunity structure for NA's inclusion into the halls of power, on the one hand, and preserved EKRE's exclusion on the other.

\section{The Latvian and Estonian party-systems: NA's inclusion versus EKRE's exclusion}

Before proceeding to the discussion of the two parties, it is essential to outline some crucial structural differences, as well as commonalities, between the Estonian and the Latvian party-systems. Although the emergence of cleavages is not a rare occurrence, Estonia has succeeded in consolidating and institutionalizing its party-system to a much greater extent in comparison to other post-Communist polities (Meleshevich, 2007; Saarts, 2011). By contrast, Latvia's party-system has been subject to higher levels of internal fragmentation and ensuing volatility (Ikstens, 2013; Saarts, 2011). One basic commonality between the two party-systems is the tendency of the ethnic Russian communities to rally around parties with a civic profile: Latvia's (nominally centre-left) Harmony and Estonia's (nominally centrist/centre-left) Centre Party. The popularity of these two 
parties among the ethnic Russians, as well as their calls for a foreign policy of appeasement vis-à-vis Russia, has rendered their political rivals sceptical, to varying degrees, over their motives and reliability. ${ }^{18}$

The latter issue requires some further elaboration and contextual analysis. In post-independence Estonia and Latvia, the state institutions have been structured in accordance to the restorationist and ethnic democracy model (Aalto, 2003; Agarin, 2016; Mole, 2012). The state institutions have been fashioned in such a way as to mirror the 'ethnic state of the Estonians/Latvians,' finally restored after its suppression by the Soviets, with an overriding emphasis on the primacy of the Estonian/Latvian languages in the state bureaucracy and the public administration (Budryte, 2005).

Nevertheless, the long-term evolution and implementation of the ethnic democracy model has varied considerably in the two countries. Since the Bronze Soldier troubles in 2007 (Ehala, 2009), the Estonian state has been providing more room for the use of the Russian language in the public administration (e.g. the police and tax authorities) and the state media (e.g. the ETV+ channel) whereas the naturalization process of 'stateless' ethnic Russians has drastically accelerated. ${ }^{19}$ By contrast, in Latvia, the state authorities insist on a stricter implementation of the ethnic democracy model. Consequently, Latvian is the only official language in the public administration, even in those parts of the country with a predominantly Russian-speaking population (e.g. the southeast region of Latgale), whereas 237,719 Russian-speakers remain 'stateless' (July 2017 figure). ${ }^{20}$

These structural realities and the different evolution of the ethnic democracy model reflect themselves upon the party-systems of Latvia and Estonia. Starting with the former, the major concern of the mainstream centre-right and conservative parties (i.e. Reform, Unity, and the Farmers and Greens Union), following the outcome of the 2010, 2011, and 2014 elections, was to prevent Harmony from forming a government. Therefore, a cordon sanitaire was built around Harmony on the basis of the party's allegedly proKremlin leanings and ensuing unreliability. It might not be an exaggeration to contend that, despite this party's considerable electoral weight, ${ }^{21}$ Harmony has been essentially viewed as the outcast party by the Latvian mainstream parties. This was the major catalyst which encouraged these parties to accept NA as a legitimate partner in two government coalitions (2011 and 2014) especially after the latter consolidated its status in the 2014 elections garnering 16.61 per cent of the vote (Table 2).

Table 2. Latvian parliamentary elections (October 2014).

\begin{tabular}{lc}
\hline Political parties & Percentages (\%) and seats \\
\hline Harmony & 23.00 (24 seats) \\
Unity & 21.87 (23 seats) \\
Union of Greens and Farmers & 19.53 (21 seats) \\
National Alliance & 16.61 (17 seats) \\
For Latvia from the Heart & 6.85 (7 seats) \\
Latvian Association of Regions & 6.66 (6 seats) \\
Latvian Russian Union & 1.58 (0 seats) \\
United for Latvia & 1.18 (0 seats) \\
Latvian Development & 0.89 (0 seats) \\
New Conservative Party & 0.70 (0 seats) \\
Freedom: Free from Fear, Hate and Anger & 0.19 (0 seats) \\
Growth & 0.17 (0 seats) \\
Sovereignty & 0.11 (0 seats) \\
\hline
\end{tabular}

Source: Latvian Electoral Committee, 2014. 
NA's successful entryism into two consecutive governments impacted on the party's pattern of policy-making in two noteworthy ways. On the one hand, NA has been granted the opportunity to promote its agenda on demographic issues and lobby for the introduction of favourable measures for large families and the subsequent provision of stimuli towards the increase of the birth rate. ${ }^{22}$ On the other hand, although not abandoning their criticism of the EU, NA affiliates now officially contend that they are not a Eurosceptic party but, instead, they '... negotiate the return of the EU to its "original" values through the revision of the Euro-federalism doctrine and the immigration policies'. ${ }^{23}$ To these should be added that NA's anti-establishment rhetoric has also become milder, despite its two constituent parties' long trajectories of political activism.

The situation in Estonia is distinctly different. The implementation of a softer variant of the ethnic democracy model has recently coincided with a greater stress on socioeconomic issues (namely social welfare), the revision of the neoliberal consensus over the management of the economy and the relative swing of Estonian politics towards the left. November 2016 saw the dissolution of the previous government coalition which consisted of the (neoliberal-orientated) Reform Party, the conservative Pro Patria and Res Publica Union-IRL and the Social Democrats-SDE. ${ }^{24}$ The steering wheel behind this development was the disagreements between the Reform Party and the SDE over the increase of taxation and the extension of welfare provisions that was proposed by the latter. Their shared pro-welfare disposition seems to have provided the essential common ground between the Centre Party and the SDE. ${ }^{25}$ This paved the way to the inclusion of the Centre Party as the largest partner (Table 1) in the government coalition that was formed in November 2016, together with the SDE and the Pro Patria and Res Publica Union-IRL. ${ }^{26}$

By contrast to NA, though, the Estonian party system did not enable EKRE to make it into the halls of power, even following the dissolution of the previous government coalition. In particular, there seems to be an explicit cleavage between SDE and EKRE in most areas of policymaking. The cleavage between the two parties intensified after the last presidential elections (2016) and Martin Helme's firm opposition to the candidacy of Marina Kaljurand (Former Minister of Foreign Affairs) on the basis of her partly Russian and partly Latvian family background. ${ }^{27}$ In addition, EKRE's platform does not seem to essentially challenge the neoliberal consensus on social welfare. ${ }^{28}$ As an aggregate of these political circumstances, whereas in Latvia the cordon sanitaire was formed around Harmony, in Estonia, the cordon sanitaire has been moulded - so far - around EKRE. In spite of its ongoing exclusion from the halls of power, EKRE's public appeal is on the rise and it stood as Estonia's third most popular party throughout 2017 and the first half of 2018 (Tables 3-6, Diagram 1).

By contrast to NA and its recently-adopted milder tones, EKRE's persistent exclusion has maintained the Euroscepticism and the anti-establishment rhetoric of the party intact. EKRE contends that the current state of political affairs in Estonia 'favours the interests of specific segments within the society in a one-sided manner' and that it is characterized by an 'excessive, often undemocratic, centralization of power with no independent vision of development' ('Konservatiivne Manifest', 2012). In accordance to EKRE's leadership, institutions such as the media also form part of the establishment. In Martin Helme's words, 'Estonian state media are always loyal to the government and this provides them with an additional incentive to depict EKRE in a negative light ... the accusations 
Table 3. Popularity ratings of political parties in Estonia (June 2018).

\begin{tabular}{lc}
\hline Political parties & Rate of popularity (\%) \\
\hline Reform Party & 28 \\
Centre Party & 27 \\
EKRE & 18 \\
Social Democrats-SDE & 9 \\
Pro Patria and Res Publica Union-IRL & 5 \\
Green Party & 4 \\
Free Party & 2 \\
\hline Source: Turu-uuringute AS, (May 29th-June & 11th, 2018; 1,000 \\
$\quad$ respondents).
\end{tabular}

Table 4. Popularity ratings of political parties in Estonia (January 2018).

\begin{tabular}{lc}
\hline Political parties & Rate of popularity (\%) \\
\hline Reform Party & 34.5 \\
Centre Party & 20.5 \\
EKRE & 18.4 \\
Social Democrats-SDE & 11.0 \\
Free Party & 5.4 \\
Pro Patria and Res Publica Union-IRL & 4.5 \\
Green Party & 4.5 \\
\hline Source: Kantar Emor, (January & 18th-25th, 2018; 1,107 \\
respondents). &
\end{tabular}

Table 5. Popularity ratings of political parties in Estonia (August 2017).

\begin{tabular}{lc}
\hline Political parties & Rate of popularity (\%) \\
\hline Centre Party & 29.0 \\
Reform Party & 24.0 \\
EKRE & 12.0 \\
Social Democrats-SDE & 12.0 \\
Free Party & 6.0 \\
Pro Patria and Res Publica Union-IRL & 5.0 \\
Green Party & 4.0 \\
\hline Source: Turu-uuringute & AS, (August \\
$\quad$ respondents). &
\end{tabular}

Table 6. Popularity ratings of political parties in Estonia (June 2017).

\begin{tabular}{lc}
\hline Political parties & Rate of popularity (\%) \\
\hline Reform Party & 25.4 \\
Centre Party & 25.1 \\
EKRE & 16.2 \\
Social Democrats-SDE & 14.2 \\
Free Party & 8.5 \\
Pro Patria and Res Publica Union-IRL & 6.6 \\
Green Party & 3.5 \\
\hline
\end{tabular}

Source: Kantar Emor, (June 9th-16th, 2017; 1,125 respondents). 


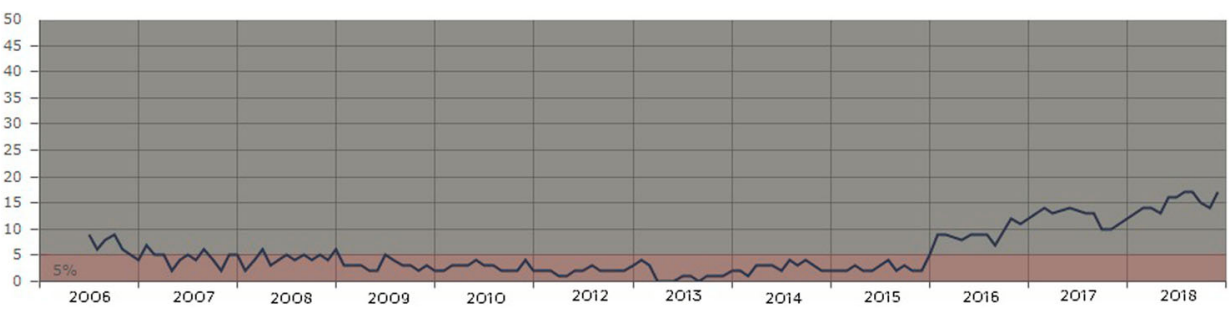

Diagram 1. *EKRE's growth of popularity (2015-2018). *The pre-2012 data refers to the People's Union of Estonia. Source: Erakonnad Monitoring Agency, 2018.

of "racism" that they often levy against us mean little to the Estonian people. ${ }^{.29}$ Certain specificities of the political landscape have, if only by default, facilitated the party's campaign. Despite the more tangible impact of the politics of consensus, in comparison to other post-Communist polities, Estonian politics have been revolving around a party system which is subject to fluidity and shifting loyalties.

Parties with conflicting standpoints (e.g. the SDE and the Reform Party on the welfare state) have often watered down their disagreements in order to form coalition governments. The crisis and dissolution of the previous government coalition is indicative of these situational alignments and the absence of long-term consensus. To this one should add that, throughout the last decade, high-profile politicians have faced charges of corruption (e.g. Edgar Savisaar during his tenure as Tallinn mayor). ${ }^{30}$ It is this intersection between malleability in policymaking and the perceptions of political corruption within the society which has enabled EKRE to build its image as 'the only true anti-establishment party in Estonia'.31

\section{EKRE, NA and (anti-)immigration: situating the present inside the context of the past}

The refugee quotas debate has generated controversies and engendered a 'centre versus periphery' cleavage within the EU: Germany versus the Visegrad Four (also Italy, the UK, etc.). Further to the northeast, the refugee crisis has, since 2015, remarkably affected the political debate and the partisan narratives in both Latvia and Estonia.

In line with the idea of preserving national sovereignty on immigration-related matters, PM Laimdota Straujuma publicly stated that Latvia was against fixed quotas for accepting refugees, calling rather for voluntary measures (May 2015). ${ }^{32}$ However, the government was also very aware of the risks of isolation vis-à-vis the EU partners if zero-sum, Visegrad-style, opposition to the relocation system was adopted as the official position. Therefore, the government preferred to engage in negotiations with Brussels, rather than opting for more hard-line alternatives. This put NA in the uncomfortable position of balancing opposition to the quotas and permanence in the governmental coalition. This issue became more complicated as the number of refugees allocated to Latvia grew from the initially proposed $40-50$ units to $766 .^{33}$

In accordance to the EU's quota arrangement, Estonia agreed to host 550 relocated persons (September 2016). ${ }^{34}$ By March 2018, 206 of them were stationed in the country (Ministry of Interior) and a refugee assistance centre has been functioning in the locality 
of Vao (Lääne-Viru county). Estonia has not been as vocal as their Central European EUpartners. Still, in former PM Taavi Rõivas' (Reform Party) words, 'the EC had made an error in its calculation and even if Estonia did welcome the refugees, the quota should be much lower'. ${ }^{35}$ Even the SDE, otherwise highly sensitive to humanitarian issues, voiced certain reservations over the Commission's directive whereas the Centre Party issued a (rejected) petition for a referendum over the maximum number of refugees that Estonia can accept (September 2016).

The respective engagements of EKRE and NA over the refugee debate have been highly conditional upon the earlier discussed dichotomy between exclusion and inclusion. Starting with the former, as early as July 2015, Martin Helme dubbed the majority of asylum seekers 'illegitimate refugees who are looking for social welfare' adding that 'if we came to power, EKRE would deport them'. ${ }^{36}$ A few months later, on 6 February 2016, EKRE intensified and internationalized its engagement via staging countrywide protests against 'the Islamization of Europe' as part of a pan-European network (comprising Germany's Pegida and other grass-roots initiatives). ${ }^{37}$ Particular attention was paid to the wave of sexual assaults in Cologne on New Year's Eve 2016 and the ensuing 'necessity to protect Estonian and European women'. These incidents were interpreted as 'the shape of things to come' for the entire Continent, if Germany and Brussels insist on an 'open borders' approach to Muslim immigration (Petsinis, 2016).

EKRE's exclusion has enabled the party to swiftly anchor its vocal campaign against the refugee quotas within the frame of its Euroscepticism and anti-establishment discourse in domestic politics (Braghiroli \& Makarychev, 2017). On the one hand, EKRE held the EU accountable for imposing its directives on Estonia in such a manner that it disregards and contravenes the will of the majority. ${ }^{38}$ On the other hand, the government was accused of ignoring the will of the people and 'lying to the public'. ${ }^{39}$ The public survey conducted by the Turu-Uuringute AS agency in March 2016 detected a clear link between EKRE's capitalization on anti-refugee rhetoric (especially after the Brussels terrorist attacks on 22 March 2016) and the party's increase of popularity. ${ }^{40}$ These observations correspond to the findings of the Erakonnad monitoring service (hosted by the TNS Emor AS agency) which equally hint at the correlation among EKRE's increasing public appeal, the intensification of the refugee quotas debate and terrorist incidents across Europe during the first half of 2016 (Cologne and Brussels, in particular) (Diagram 1). ${ }^{41}$

In Latvia, even the virtual debate over the refugee quotas triggered a string of protests, organized by grass-roots groupings such as the Guardians of the Fatherland, throughout 2015 and 2016. ${ }^{42}$ By contrast to EKRE's dynamic engagement and mobilization, though, NA's operation from within the halls of power called for a more gradualist strategy. At a first instance, this consisted in an attempt to align with and take advantage of the widespread reservations over the fixed quotas arrangement, as well as the shared preference for 'case-specific' solutions in accordance to the specificities of each member-state, among the majority of parties in the parliament (Harmony included).

Consequently, in May 2015, the NA faction leader in the government, Imants Parādnieks, stated that: 'there are no international obligations requiring Latvia to accept any refugee quotas. Latvia has the right to determine its own migration policy rather than thoughtlessly follow the ideological framework set by the EC for resolving this refugee issue'. ${ }^{43}$ At a second instance, the NA-affiliates started to interlink the refugee debate with state security and national survival more concretely and emphatically. Therefore, 
the party leadership started urging the government to 'act responsibly regarding this sensitive national security issue and in talks with foreign partners to express this position, which has the support of the majority in Latvian society'. ${ }^{44}$ In a similar spirit to the Bauska Declaration and its take on the 'failed' Western immigration policies, Janis lesalnieks, a senior official at the Justice Ministry and prominent member of NA, hinted at the toll that the refugee quotas can claim on Latvia's demographic realities by bringing up the Swedish precedent: 'Is this what we want in Latvia? 127,000 immigrants arrived in Sweden in 2014 but meanwhile 115,000 children were born (including immigrant families) ${ }^{\prime} .45$

In spite of the dichotomy between exclusion and inclusion, though, both EKRE and NA converged in their endeavour to interlink the post-war planned migration project under the Soviets with the new realities of the refugee issue. From a theoretical angle, locating the past in the context of the present is a common technique among nationalist actors which helps interpret developments along a linear trajectory and satisfy the quest for meaning among their bases of support (Connor, 1993; Smith, 2000, pp. 82-83). Furthermore, the origins of anti-immigrant sentiments may vary considerably from one society to the other and political parties or groupings that put a high stress on the hard borders principle tend to anchor their narratives primarily into symbols and imageries derived from their own societies' historical experience.

In this light, NA's lawmaker, Janis Dombrava, resorted to the ethno-cultural argument and hinted at the massive inflow of non-autochthonous population after the Second World War stating that Latvia already had the highest level of 'other ethnicities' in the EU, therefore, further immigration is 'not possible'. ${ }^{46}$ NA embeds opposition to the refugee quotas into its rejection of Euro-federalism and, if only subtly, has been seeking to draw parallels between the EU's management of the refugee crisis and the state-sponsored migration under the Soviets. In Edvins Šnore's words, 'Mr. Juncker obviously wants to reduce the sovereignty of nations' adding that 'the EC's approach is very naïve: Bring the refugees to states like Latvia (or Estonia) and the problem will be miraculously solved! The bulk of the refugees that we accepted preferred to move to Scandinavia and/or Germany'. 47

In a similar vein, EKRE's campaign against the admission of refugees possesses an idiosyncratic socio-psychological dimension. It capitalizes on the collective memories of 'colonization' under the Soviets (Hallik, 2002, p. 71; Kreindler, 1988, p. 11 and 13; Peiker, 2016, pp. 120-123) and the collective fears of becoming 'colonized' again by others in the future. Apart from the influx of war refugees from the Middle East, the party remains equally concerned over the '(East) Slavic immigration to Estonia' ('Eurovalimiste Platvorm', 2014) because this may allegedly result in 'a new colonization and the demographic prevalence of Russophones over Estonians in the next 30 years'. ${ }^{48}$ Under this light, it is no coincidence that allusions to the Soviet era and the Russification campaign interweave in EKRE's rhetoric with references to the threat that immigration allegedly poses to national survival. As the former Estonian President, Toomas Hendrik Ilves, subtly hinted, public reservations over the refugee question and immigration should not be disconnected from the 'colonization' under the Soviets and its long-term ramifications on the society. ${ }^{49}$

In addition to situating the present inside the context of the past, the socio-psychological strategy of the two parties also embodies a preemptive dimension which is centred on the future. In Martin Helme's words, 'Global terrorism poses a security threat for Estonia 
but this is lower in comparison to Western Europe. However, the refugee quota arrangement, dictated by the EU, can generate potential perils in the immediate future'. ${ }^{50} \mathrm{NA}^{\prime} \mathrm{s}$ leadership equally tends to draw a tentative correlation between the (increased) physical presence of Muslim communities and the future prospects for the import of terrorism and/ or other asymmetric threats. In Edvins Šnore's words, 'Latvia is mostly safe from global (literally Islamic) terrorism because we only have a tiny Muslim community. The larger the Muslim minority, the greater the security risk can be (e.g. France, Belgium, or Germany)'. ${ }^{51}$ This viewpoint is seconded by Raivis Zeltits who judges that

the real threat is connected with the existence of a Muslim minority within the state. If you look at the UK or France, ghettoization, crime and the spread of Islamic fundamentalism constitute an explosive blend. Latvia is and will remain safe if it manages to escape the migration waves. $^{52}$

Therefore, identity-politics and their selective appropriation seem to have gained precedence over the minuscule presence of war refugees in Latvia and Estonia and evolved into a key component in EKRE's and NA's campaigns. This development is largely in accordance with the intersection among Euroscepticism, anti-immigration and the allusions to the collective trauma inherited from the Soviet era in the text of the Bauska Declaration. At a first instance, NA's entryism dictated a more gradualist strategy on the party's behalf over the refugee question. In the longer term, though, this entryism seems to have enabled the party to promote its standpoints more effectively and from within the government structures.

Meanwhile, EKRE's persistent exclusion appears to provide plenty of room for this party's more dynamic engagement with the objective to capitalize on the public grievances vis-à-vis the Estonian establishment and the EU over the management of the refugee crisis. Setting the inclusion versus exclusion dichotomy aside, there is an additional common denominator which facilitates the political engagement of both parties over the refugee issue. This is, namely, the shared reservations of most Estonian and Latvian parties over the fixed quotas and their preferences for case-specific arrangements on the basis of each member-state's particularities and specificities.

\section{Conclusions}

The objective of this piece was to comparatively investigate the developmental trends of the two main populist and radical right-wing parties in Latvia and Estonia, by looking at the exogenous impact of each country's party system and at the related endogenous dimensions of identity politics on the parties' capacity to establish themselves as acceptable governmental partners and avoid marginalization. The context of the ongoing refugee crisis and the ensuing virtual debate was examined as a trigger to explore the reactions of these political forces to the new realities, rather per se.

The comparative analysis of the narratives and strategies of the two parties highlighted evident similarities in terms of ideological platforms and programmatic priorities. Both parties emerged as anti-establishment and nativist forces, with a powerful emphasis on the ethno-national definition of their respective policies (Connor, 1993), thereby stressing aspects related to the protection of the status of the national languages from the heritage of the Soviet past and their role as the only genuine 
representatives of the deep essence of the nation, betrayed by its corrupt and distant elites. EKRE and NA also proved champions of Euroscepticism and in the opposition to postmodern values such as LGBT rights or multiculturalism, as highlighted in the Bauska Declaration.

The analysis highlighted certain endogenous differences in the developmental trends of the two forces that seemingly have played a significant role in their chances to be considered legitimate coalition partners by more mainstream forces. Our study shows that if compared to Estonia's EKRE, NA can boast a longer tradition of political activism and, following the merger between TB-LNNK and 'All for Latvia,' the party managed to combine the structures of the former with the fresh energies of the latter. At the same time, the party slowly, but steadily, watered down its anti-establishment rhetoric and progressively down-toned its degree of Euroscepticism in order to adapt to this new centrality in the Latvian party system.

In the light of both endogenous and exogenous factors, in Latvia, NA has succeeded in consolidating its status and successfully established itself as one of the countries' key forces. Accordingly, its acceptance by the other partners is witnessed by its participation in every government of Latvia since the 2011 parliamentary elections, as part of the joint endeavour to prevent Harmony (i.e. the essentially outcast party in this context) from entering the government structures. It might not be an exaggeration to contend that NA's strategy represents an exceptional example of successful entryism.

In Estonia, on the contrary, EKRE - despite the steady increase of its public appeal - has been excluded from any prospects to enter a government coalition precisely due to the successful inclusion of the Centre Party. In 2016, the Centre Party - under its new leadership - successfully formed a government with SDE and IRL. At the same time, EKRE's pattern of interaction with the mainstream parties appears rather volatile and complicated (if compared to NA in the Latvian case), therefore, EKRE currently fits the profile of an outcast party to a considerable degree. In both cases, a combination of endogenous and exogenous factors seems to condition the position of these parties in the respective party systems.

The analysis of the developmental trends in the cases of EKRE and NA seems to highlight how the exclusion of the former and the inclusion of the latter are due to both endogenous factors related to the particularities of each context's identity politics and exogenous differences in the two-party systems when dealing with parties suspected of pro-Kremlin leanings - respectively, Estonia's Centre Party and Latvia's Harmony.

When it comes to the specificities of each context's identity politics, particularly telling appears the analysis of the parties' strategies when it comes to the ongoing refugee crisis, which - in the context of the Baltics - assumes the features of a virtual debate, given the very limited number of refugees accepted and the low attractiveness of the two countries in the eyes of many migrants. Despite its virtual nature, both in Latvia and Estonia, the debate - often representing a shortcut to address issues such as multiculturalism, postmodernism, terrorism, and national identity - has very vividly affected the political dynamics and partisan stances, since 2015.

In the Estonian case, EKRE's anti-immigration stances have taken a strong anti-establishment turn, the main objectives of which appeared to be the mainstream parties, guilty of having 'sold Estonia to Brussels', thereby reflecting the party's outcast status and counterhegemonic position in the Estonian party system. In the Latvian case, NA has elaborately 
combined populist slogans against Brussels and the transnational elites, as well as a powerful anti-refugee rhetoric, with a pragmatic behaviour vis-à-vis the coalition partners in order to retain its key role in the government. At the same time, NA has managed to exert a non-negligible impact (towards a conservative direction) on nearly every governmental decision which pertains to immigration, asylum, and - broadly defined, multiculturalism.

\section{Notes}

1. The present article was finalized before the Latvian parliamentary elections of October 2018.

2. The MSSD applies both to the parties analyzed and to the domestic, in Mudde's words, ethnocratic contexts - Estonia and Latvia - in which they operate.

3. In 1991, the Lithuanian state automatically granted universal citizenship to all residents. By contrast, the main bulk of post-war settlers in Estonia and Latvia, mostly ethnic Russians, were rendered 'stateless' and had to start a complex process of naturalization - including also strict language requirements - in order to obtain the citizenship of the newly-independent republics.

4. It should be noted that, apart from NA, Latvia's party landscape also comprises other rightwing parties with a nationalist orientation (e.g. 'For Latvia from the Heart'/NSL). However, the focus of this piece is cast on NA, on the basis of this party's greater electoral weight, continuous participation in the government structures and established partnership with EKRE.

5. EKRE (2013). 'Bauska Deklaratsioon'. (https://ekre.ee/bauska-deklaratsioon/). A full text-version in English can be accessed on: http://tautininkas.blogspot.com.ee/.

6. The People's Union was a partner in the large electoral coalition (the Estonian Coalition Union) during the second legislature (1995-1999) and then again between 2003 and 2007.

7. http://www.delfi.ee/archive/print.php?id=64124549.

8. It should be noted that this party had been in almost every government since 1995: first as TB and LNNK separately, then also after their merge into TB/LNNK.

9. In the 2015 elections, EKRE was the third strongest party in the western district of Pärnumaa. On this issue, see: http://rk2015.vvk.ee/voting-results-12.html.

10. In its programme, EKRE vows to uphold 'Christian family values and the traditional family model which consists of a father, mother, and children' ('Perekond' section).

11. http://www.nacionalaapvieniba.Iv/video/raivis-zeltits-intermarium-un-eiropas-nakotne/.

12. http://www.neweasterneurope.eu/articles-and-commentary/2367-a-far-right-hijack-of-interm arium.

13. https://www.ilga-europe.org/sites/default/files/Attachments/latvia_-_homophobic_speech_ in_latvia_english.pdf.

14. http://reconquista-europe.tumblr.com/post/156974224221/agris-purvi $\% C 5 \% 86 \% C 5 \% A 1$-inte rmarium-as-a-civilizational.

15. Interviews with the Secretary-general of the Latvian National Alliance and a National Alliance representative at the Latvian Saeima (assembly) and the European parliament (13/10/2017); Interview with the Vice Chairman of EKRE (12/10/2016).

16. Interview with the Secretary-general of the Latvian National Alliance (13/10/2017).

17. As understood within the frame of this piece, the concept of nativism holds that primacy must be given to the political rights, the economic needs and the cultural identity of the ethnic/ native members of the titular nations. For a more thorough discussion of nativism and how it differentiates from populism, see Pappas (2018).

18. A remarkably controversial watershed for the two parties was their decision to sign memorandums of cooperation with Vladimir Putin's United Russia (Centre Party: 2004; Harmony: 2009). Both agreements focused on cooperation and exchange of information over the economy and other policy-areas but were never actually implemented since then. However, this sufficed for rival parties in both countries to capitalize on these two agreements as 
major indicators of unreliability on the part of Harmony and the Centre Party. In the Latvian case, this mood of apprehension has been persisting even after Harmony cancelled its memorandum of cooperation (October 2017). On Estonia, see: http://news.err.ee/119629/overviewcenter-party-s-cooperation-protocol-with-putin-s-united-russia. On Latvia, see: https://news. err.ee/635146/latvia-s-saskana-party-ditches-agreement-with-putin-s-united-russia.

19. On 21 January 2015, the parliament introduced a new set of amendments to the Law on Citizenship. A stateless child born in Estonia to parents with 'undetermined citizenship', who have lived in Estonia for at least 5 years before the child's birth, is automatically eligible to obtain citizenship. Whereas, in 2004, the percentage of stateless individuals corresponded to approximately 12.5 per cent of the total population (i.e. 172,000 persons) (Van Elsuwege, 2004), by 2017, the total number of 'stateless persons' had dropped to 79,300. On the latter issue, see: $\mathrm{http} / / \mathrm{www}$.statelessness.eu/blog/fight-voting-rights-stateless-persons-estonia-and-latvia.

20. http://www.pmlp.gov.lv/lv/assets/documents/ledzivotaju\%20re\%C4\%A3istrs/010717/ISVP_La tvija_pec_VPD.pdf.

21. Harmony emerged as the strongest party in its own right, in the 2011 and the 2014 elections, garnering 28.36 per cent and 23 per cent of the vote respectively.

22. Interview with an academic expert on populism at Latvia University (28/07/2017).

23. Interviews with the Secretary-general of the Latvian National Alliance and a National Alliance representative at the Latvian Saeima and the European parliament (13/10/2017).

24. http://news.err.ee/v/news/952dcb2e-bb26-4c32-a87a-0a4f073fec01/government-falls-as-soci al-democrats-and-irl-leave-coalition.

25. One complementary development which facilitated the inclusion of the Centre Party to the new government was the departure of Edgar Savisaar from the party-leadership (2016). A veteran politician and entrepreneur, Savisaar had been leading the Centre Party throughout the post-Communist era. This development coincided with the emergence of a reformist segment consisting of younger cadres (e.g. the current chairman of the Centre Party and Estonian PM, Jüri Ratas).

26. It should be borne in mind that the Centre Party had participated in the coalition government that was formed after the 1995 elections. Edgar Savisaar became Minister of Internal Affairs, while the Centre Party became in charge of four more ministries (Social Affairs, Economy, Education and Transportation and Communications). The Centre Party also formed part of the coalition government between 2002 and 2003.

27. http://balticworlds.com/finally-breaking-the-deadlock/.

28. EKRE's programme provides for an increase in the minimum wage and state-pensions that can guarantee a decent living ('Sotsiaalpoliitika' section). However, the party also contends that the people's well-being must rely on the overall development of the economy and not solely on social benefits (including a pledge to recall unjustified pensions and benefits) (Ibid.)

29. Interview with the vice chairman of EKRE (12/10/2016).

30. http://news.err.ee/v/politics/2b68a0b6-7636-4070-8389-f9751d5874a4/savisaar-suspended-fr om-mayors-office.

31. Interview with a political sociologist at Tallinn University (08/06/2016). Moreover, the survey conducted by the sociologist Juhan Kivirähk for the Turu-uuringute AS agency (March 2018) found out that the party's anti-establishment rhetoric resonated with the low trust of two-thirds of its voters (the lowest among all parties) to the parliament, the government and the President. On this issue, see: https://www.err.ee/692131/kivirahk-tahtis-pole-seemida-sinust-raagitakse-vaid-et-uldse-raagitakse.

32. http://www.baltic-course.com/eng/legislation/?doc=106034\&output=d\&ins_print.

33. http://eng.lsm.Iv/article/society/society/interior-minister-we-agreed-to-relocate-not-admit-53 1-refugees.a156528/.

34. http://news.err.ee/v/179fof5d-0a10-459c-b26e-4c714e38ba7b.

35. http://news.err.ee/v/55ea4612-1abb-4cee-95ef-91e4bc775df9.

36. http://news.err.ee/v/8728b4fd-d8c5-4c5b-b89e-93a608f381f0.

37. http://news.err.ee/v/6614e41a-1fb7-4b87-a205-987d4b1a77d5.

38. Interview with the Vice-chairman of EKRE (12/10/2016). 
39. http://news.err.ee/v/f58cb255-07ed-4cac-b0f9-e6f65ca43f83.

40. In accordance to the findings of this survey, EKRE's popularity jumped from an estimated 13 per cent to 19 per cent immediately after the Brussels bombings. On this issue, see: http:// www.postimees.ee/3637703/uuring-bruesseli-terroriruennak-tostis-ekre-toetuse-reformierako nna-kannule.

41. http://www.erakonnad.info/reiting.html.

42. https://www.baltictimes.com/anti-refugee_rally_takes_on_latvian_government_2680716675 5c21627948b7/.

43. http://eng.Ism.Iv/article/politics/politics/lawmakers-reluctant-to-take-in-refugees.a128591/.

44. http://eng.lsm.lv/article/politics/politics/latvia-to-lodge-objection-to-refugee-quotas.a129119/.

45. http://eng.lsm.Iv/article/society/society/refugee-numbers-known-in-a-month-says-pm. a135277/.

46. http://eng.lsm.Iv/article/politics/politics/lawmakers-reluctant-to-take-in-refugees.a128591/.

47. Interview with a National Alliance representative at the Latvian Saeima (assembly) and the European parliament (13/10/2017).

48. Interview with the Vice-chairman of EKRE (12/10/2016).

49. http://news.err.ee/v/55ea4612-1abb-4cee-95ef-91e4bc775df9

50. Interview with the Vice Chairman of EKRE (12/10/2016)

51. Interview with a National Alliance representative at the Latvian Saeima (assembly) and the European parliament (13/10/2017)

52. Interview with the Secretary-general of the Latvian National Alliance (13/10/2017).

\section{References}

Aalto, P. (2003). Constructing post-Soviet geopolitics in Estonia. London: Routledge.

Agarin, T. (2016). Extending the concept of ethnocracy: Exploring the debate in the Baltic context. Cosmopolitan Civil Societies, 1-19. doi:10.5130/ccs.v8i3.5144

Auers, D., \& Kasekamp, A. (2009). Explaining the electoral failure of extreme-right parties in Estonia and Latvia. Journal of Contemporary European Studies, 17(2), 241-254.

Auers, D., \& Kasekamp, A. (2013). Comparing right wing populism in Latvia and Estonia. In R. Wodak, M. Khosravinik, \& B. Mral (Eds.), Right-wing populism in Europe: Politics and discourse (pp. 235-248). London: Bloomsbury.

Auers, D., \& Kasekamp, A. (2015). The impact of radical right parties in the Baltic states. In M. Minkenberg (Ed.), Transforming the transformation. The East European radical right in the political process. London \& New York: Routledge.

Braghiroli, S., \& Makarychev, A. (2017). Redefining Europe: Russia and the 2015 refugee crisis. Geopolitics, doi:10.1080/14650045.2017.1389721

Budryte, D. (2005). Taming nationalism? Political community building in the post-Soviet Baltic states. Aldershot: Ashgate.

Callaghan, J. (1986). The background to 'entryism': Leninism and the British labour party. Journal of Communist Studies, 2, 380-403.

Connor, W. (1993). Ethnonationalism: A quest for understanding. London: Routledge.

Dudai, R. (2017). Entryism, mimicry and victimhood work: The adoption of human rights discourse by right-wing groups in Israel. The International Journal of Human Rights, 21(7), 866-888.

Ehala, M. (2009). The bronze soldier: Identity threat and maintenance in Estonia. Journal of Baltic Studies, 40(1), 139-158.

EKRE. (2012). Konservatiivne Manifest. Retrieved from https://ekre.ee/konservatiivne-manifest/

EKRE. (2013). Bauska Deklaratsioon. Retrieved from https://ekre.ee/bauska-deklaratsioon/

EKRE. (2014). Eurovalimiste Platvorm. Retrieved from https://ekre.ee/eurovalimiste-platvorm/

EKRE. (2015a). Konservatiivne Programm. Retrieved from https://ekre.ee/konservatiivne-programm/

EKRE. (2015b). Riigikogu 2015. Retrieved from https://ekre.ee/riigikogu-2015/

Hallik, K. (2002). Nationalizing policies and integration challenges. In M. Lauristin, \& M. Heidmets (Eds.), The challenge of the Russian minority: Emerging multicultural democracy in Estonia (pp. 65-88). Tartu: Tartu University Press. 
Hanley, S. (2004). Getting the right right: Redefining the centre-right in post-communist Europe. Journal of Communist Studies and Transition Politics, 20(3), 9-27.

Ikstens, J. (2013). Latvia. In J.-M. De Waele, F. Escalona, \& M. Vieira (Eds.), The Palgrave handbook of social democracy in the European Union (pp. 470-487). Palgrave Macmillan (Kindle edition).

Interview with an academic expert on populism at Latvia University (28/07/2017).

Interview with a National Alliance representative at the Latvian Saeima (assembly) and the European parliament (13/10/2017).

Interview with a political sociologist at Tallinn University (08/06/2016).

Interview with the Secretary-general of the National Alliance (13/10/2017).

Interview with the Vice-chairman of EKRE (12/10/2016).

Jackson, P., \& Davies, P. (2008). The far right in Europe: An encyclopaedia. Oxford, CT: Greenwood.

Kasekamp, A. (1999). Radical right-wing movements in the Northeast Baltic. Journal of Contemporary History, 1(1), 587-600.

Kelley, J. (2004). Ethnic politics in Europe: The power of norms and incentives. Princeton, NJ: Princeton University Press.

Kreindler, I. (1988). Baltic area languages in the Soviet Union: A sociolinguistic perspective. Journal of Baltic Studies, 19(1), 5-20.

Lieven, A. (1994). The Baltic revolution: Estonia, Latvia, Lithuania and the path to independence. New Haven and London: Yale University Press.

\section{LIST OF ELITE AND EXPERT INTERVIEWS}

Meleshevich, A. (2007). Party systems in post-Soviet countries: A comparative study of political institutionalization in the Baltic States, Russia, and Ukraine. Basigstoke: Palgrave Macmillan.

Minkenberg, M. (Ed.). (2015). Transforming the transformation? The East European radical right in the political process. London-New York: Routledge.

Minkenberg, M. (2017). The radical right in Eastern Europe: Democracy under siege? New York: Palgrave Macmillan.

Mole, R. (2012). The Baltic states from the Soviet Union to the European Union: Identity, discourse and power in the post-communist transition of Estonia, Latvia and Lithuania. London: Routledge.

Mudde, C. (2007). Populist radical parties in Europe. Cambridge: Cambridge University Press.

Nacionālā Apvienība. (2017). Programma. Retrieved from http://www.nacionalaapvieniba.lv/ programma/

Pappas, T. (2018). How to tell nativists from populists. Journal of Democracy, 29(1), 148-152.

Peiker, P. (2016). Estonian nationalism through the postcolonial lens. Journal of Baltic Studies, 47(1), 113-132.

Petsinis, V. (2016, April 28). Contentious politics in the Baltics: The "new" wave of right-wing populism' in Estonia. Open Democracy. Retrieved from https://www.opendemocracy.net/author/ vassilis-petsinis

Pirro, A. L. (2013). Populist radical right parties in Central and Eastern Europe: The different context and issues of the prophets of the Patria. Government and Opposition, 1-30. doi:10.1017/gov.2013.32

Pytlas, B. (2015). The populist radical right in Central and Eastern Europe: Ideology,impact, and electoral performance. London \& New York: Routledge.

Saarts, T. (2011). Comparative party system analysis in Central and Eastern Europe: The case of the Baltic states. Studies of Transition States and Societies, 3(3), 83-104.

Smith, A. D. (2000). The nation in history: Historiographical debates about ethnicity and nationalism. Oxford: Oxford University Press.

Tarrow, S. (2010). The strategy of paired comparison: Toward a theory of practice. Comparative Political Studies, 43, 230-259. doi:10.1177/0010414009350044.

Van Elsuwege, P. (2004). Russian-speaking minorities in Estonia and Latvia: Problems of integration at the threshold of the European Union. Flensburg: ECMI Press.

van Kessel, S. (2015). Populist parties in Europe: Agents of discontent? Basingstoke: Palgrave Macmillan. Webber, P. (2009). Entryism in theory, in practice, and in crisis: The Trotskyist experience in New Brunswick, 1969-1973. Left History, 14(1), 33-57. 